\title{
Biotechnology in the ex situ Conservation of Endemic, Rare and Threated Plant Species
}

\author{
Selda Sonmez \\ Ege University, Science Faculty, Biology Department, \\ Botany Section 35100, Bornova-Izmir/Turkey \\ Esin Oluk (Corresponding author) \\ Ege University, Science Faculty, Biology Department, \\ Botany Section 35100, Bornova-Izmir/Turkey \\ E-mail: esin.oluk@ege.edu.tr \\ “This study was prepared from Selda Sonmez's diploma thesis”
}

\begin{abstract}
Plant species in the world are largely under threat, especially due to the climate change that makes us feel more today. Other threatening reasons include industrial wastes, poor agricultural practices, and poor use of forest land besides increase in human population. Accordingly, many strategies and methods have been developed to protect plants. These methods are basically grouped under two headings as conservation of plants in their natural environment (in situ) and conservation with different methods other than their natural environment (ex situ). In this study, ex situ and in situ strategies developed for the purpose of protecting plants and biotechnological conservation methods, which have been added to ex situ strategies and gained importance in recent years, have been examined.
\end{abstract}

Keyword: Plant conservation biology, ex situ conservation, in situ conservation, endemic, biotechnology, tissue culture

DOI: $10.7176 / \mathrm{JSTR} / 6-04-02$

\section{Endemik, Nadir Bulunan ve Tehdit Altındaki Bitki Türlerinın ex situ Korunmasında Biyoteknoloji}

\begin{abstract}
Özet
Günümüzde bitki türleri, özellikle giderek kendini daha çok hissettiren iklim değişikliği nedeniyle, büyük ölçüde tehdit altındadır. Tehdit oluşturan diğer gerekçeler arasında sanayi atıkları, kötü tarım uygulamaları, orman arazilerinin kötü kullanımı ile hızlanan insan nüfus artı̧ı gösterilmektedir. $\mathrm{Bu}$ doğrultuda, bitkileri koruma altına almak üzere çok sayıda strateji ve yöntem geliştirilmiş̧ir. $\mathrm{Bu}$ yöntemler temelde, bitkileri doğal ortamlarında koruma (in situ) ve doğal ortamlarının haricinde farklı yöntemlerle koruma (ex situ) olarak iki başlık altında toplanmaktadır. Bu çalışmada, bitkileri koruma amacıyla geliştirilen bu stratejiler ve özellikle ex situ stratejilere son yllarda eklenen ve giderek önem kazanan biyoteknolojik koruma yöntemleri ilgili literatürden hareketle irdelenmiş̧ir
\end{abstract}

Anahtar Kelimeler: Bitki koruma biyolojisi, ex situ koruma, in situ koruma, endemik, biyoteknoloji, doku kültürü

\section{Giriş}

Bitkiler, primer üreticiler olma özelikleriyle, ekosistemlerin kararlılı̆ını ve dengesini sağlamada anahtar canlılardır (Chapin, 2003). Bitki gen kaynakları, biyolojik çeşitliliğin hayati bir parçasını ve insan sağlığının da temel kaynağını oluştururlar (Alho, 2012). Ancak, kendini günden güne daha çok hissettiren iklim değişikliği, kötü tarım uygulamaları, orman arazilerinin kötü kullanımı, toksik sanayi atıkları ile hızlanan insan nüfus artışı gibi çoğunluğu antropojenik nedenlerle bugün bitkilerin nesli yok olma tehlikesiyle karşı karşıyadır (Hunter, 2007). Tüm bu nedenlerle sanayi devriminden bu yana 600e yakın 
bitki türünün yok olduğu, incelenebilen 150000 türün \% 10u'nun ise yok olma tehlikesi altında bulunduğu belirtilmektedir (IPBES Raporu, 2019). IUCN (International Union for the Conservation of Nature and Natural Resources =Uluslararası Doğayı ve Doğal Kaynakları Koruma Birliği) adlı kuruluş (https://www.iucnredlist.org/) yok olma tehdidini kategorilere ayırmış ve bu kategorileri "kırmızı liste" olarak nitelemiştir (şekil 1).

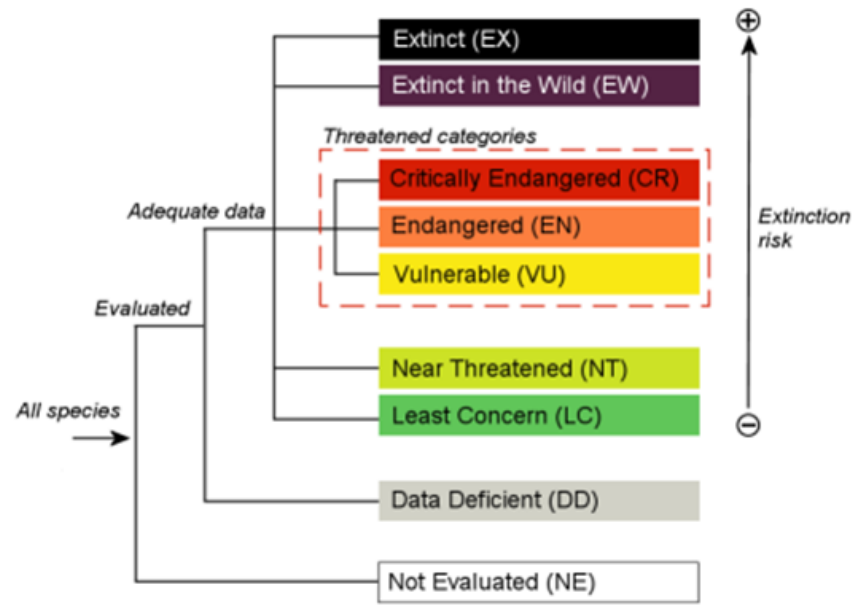

Şekil 1- Türlerin yok olma tehlikesi kategorizasyonu (http://www.iucnredlist.org/technical-documents/categories-and-criteria/2001-categoriescriteria\#definitions)

$\mathrm{Bu}$ listenin amacı tehlike kategorizasyonunun (şekil 1) nispeten yüksek küresel tükenme (kritik olarak tehlikede (CR)), tehlikede (EN) ve tehdide açık (VU)) seviyelerindeki taksonları kataloglamak ve dikkatleri bu taksonların üzerine çekmektir (Sarasan vd., 2006). Bitki çeşitliliğinin kaybolmasına yönelik bu alarm verici durum çok önceleri dünya çapında bilim insanlarını harekete geçirmiş ve "bitki çeşitliliğini koruma" temalı dev bir çalışma alanını ortaya çıkarmıştır. Bu konudaki en önemli girişimlerden biri, 2002 yılında Lahey'de yapılan altıncı Biyolojik Çeşitlilik Kongresi'nde "Bitki Korumasında Küresel Strateji Geliştirilmesinin" kabulü olmuştur (https://sdg.iisd.org/news/sixthconference-of-the-parties-to-the-convention-on-biodiversity-cbd-cop-6/) . Strateji, bitki çeşitliliğinin, bitki kommunitelerinin ve ekosistemlerin in situ (doğal bölgesinde) ve/veya ex situ (doğal bölgesinin dışında) $i$ ) uzun süreli korunmalarını, ii) yönetimlerini ve, iii) restorasyonlarını içermektedir (Vinoth ve Ravindran, 2013). Çoğunlukla, bu iki yöntem, bir türün korunmasında birbirini tamamlayıcı olarak kullanılır (Tormann, 2006).

$\mathrm{Bu}$ çalışmada, bitkileri in situ ve ex situ koruma amacıyla yapılan çalışmalar özetlenerek; ex situ çalışmalar arasında günümüzde giderek daha çok rağbet gören biyoteknolojik koruma yöntemlerinin neler olduğu, avantajları ve dezavantajları detaylarıyla verilmeye çalışılmıştır.

\section{In situ Koruma}

$\mathrm{Bu}$ kavram, bitkileri kendi doğal yaşam alanlarında koruma altına almak anlamına gelmektedir (Heywood, 2014). Böylece germplazm doğada, bulunduğu habitat içerisinde doğal haliyle korunmaktadır. Bu yöntemde türün evrimsel süreci kesintiye uğramaz. Ancak ilgili ekosistemin insan etkisinden korunması yüksek maliyet gerektirmektedir (Li ve Pritchard, 2009). Bu doğal yaşam alanlarına örnek olarak, doğal rezerv alanları, milli parklar ve biyosfer rezerv alanlarl verilebilir (https://whc.unesco.org/en/list/219).

Doğal rezerv alanı, doğal hayatın sürdürülebilirliğinin sağlanması yönünden önemli bir coğrafyaya, bitki- hayvan türlerine ve jeolojik oluşumlara sahip olup bilimsel araştırma ve sonuçlarla yönetilen özel bölge anlamına gelmektedir (Frankel ve Soule, 1981)(şekil 2). 


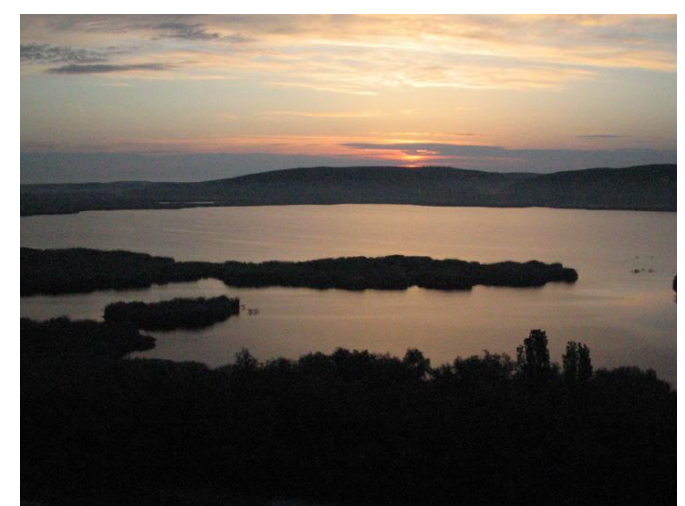

Şekil 2- Sreberna Doğa Rezervi (Bulgaristan). Avrupa'nın, Volga'dan sonra ikinci büyük nehri olan Tuna nehri yakınlarında ve yaklaşık 600 ha büyüklüğünde bir tatlı su gölüdür.

(https://whc.unesco.org/en/list/219)

Milli parklar, bilimsel ve estetik açıdan ulusal ve uluslararası ölçüde ender bulunan doğal ve kültürel kaynakları barındıran aynı zamanda turizme açık bölgelerdir (şekil 3).

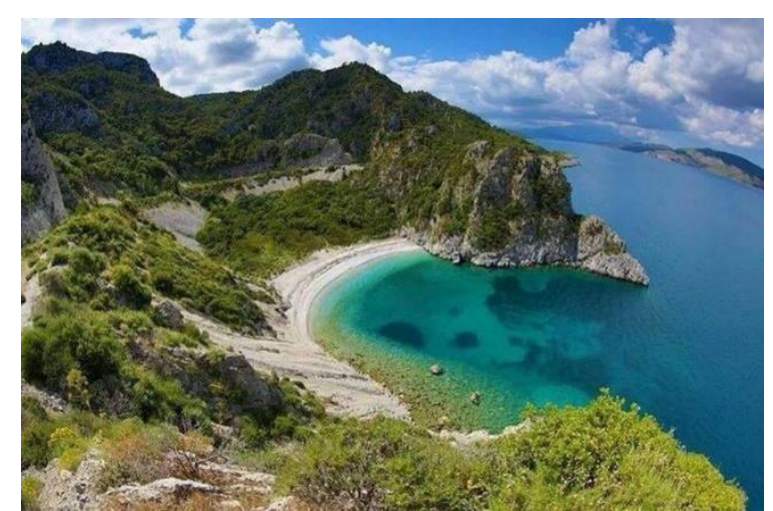

Şekil 3- Kuşadası Milli Parkı/Aydın (https://neyerdenegokte.com/kusadasi-guzel-camli-milli-parki/)

Biyosfer Rezervleri, insan ve doğa arasındaki ekolojik, ekonomik, kültürel ve sosyal açıdan dengeli ve sürdürülebilir ilişkilerin kurulduğu ve UNESCO'nun İnsan ve Biyosfer (MAB:Man and Biosphere) Programı içerisinde yer alan karasal ve/veya kıyı ekosistemlerine sahip alanlardır (http://www.unesco.org/new/en/natural-sciences/environment/ecological-sciences/biosphere-reserves/) (Şekil 4,5)

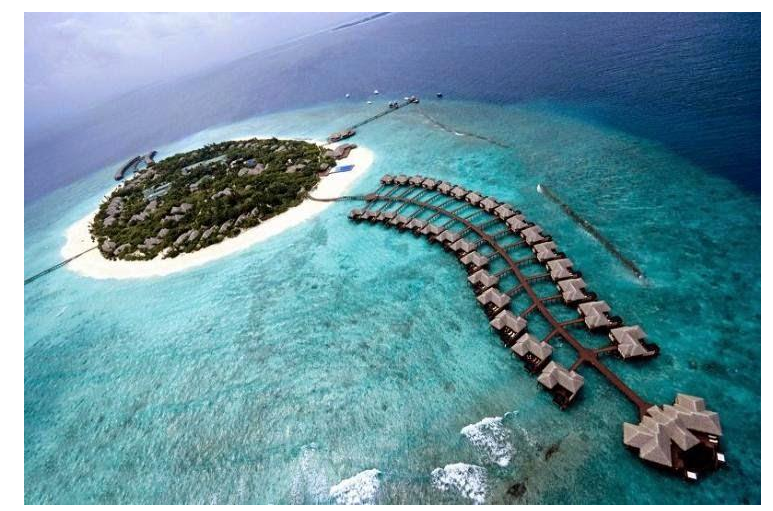

Şekil 4- Mannar Körfezi Biyosfer Reservi/Hindistan.

(http://game3527.timetosearch80.loan/?utm_medium=NQ3aDvyuBCtafRQJPeFC66tm\%2bMNW8T\%2 baflxPOdOAJGo\%3d\&t=main3) 


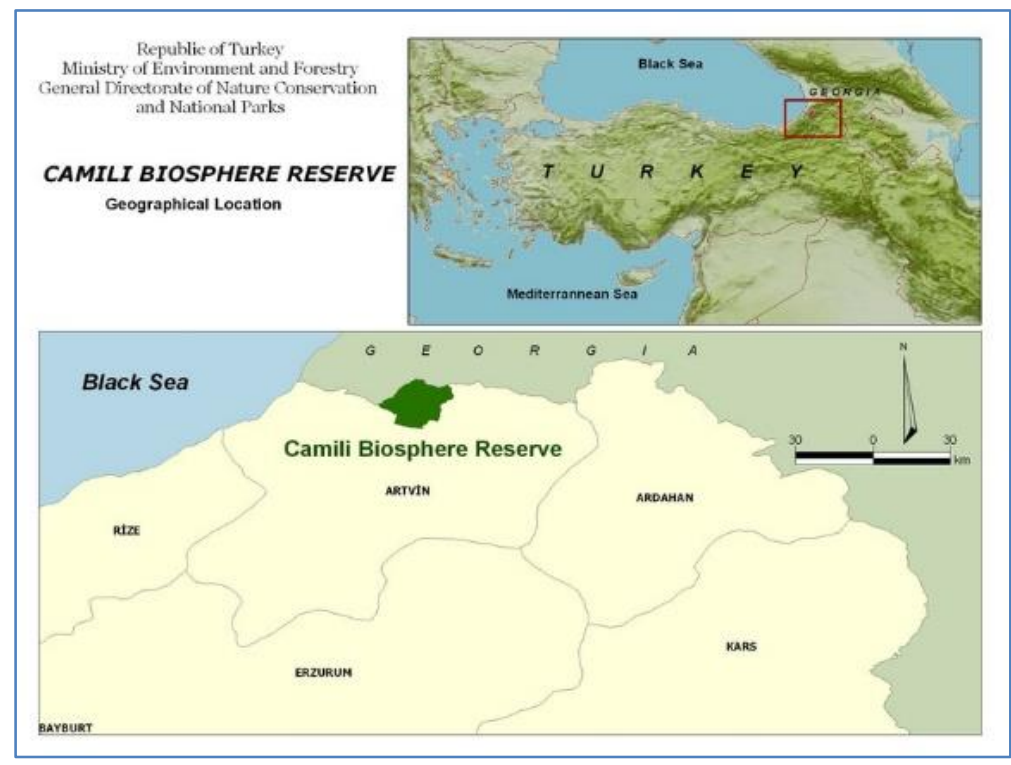

Şekil 5- Artvin ili, Borçka ilçesi sınırları içindeki Camili Biyosfer Rezervi; Türkiye'nin ilk ve tek biyosfer rezervidir. 29 Haziran 2005'te Dünya Biyosfer Rezervleri Ağı'na dahil olmuştur.

(http://www.unesco.org/new/en/natural-sciences/environment/ecological-sciences/biospherereserves/europe-north-america/turkey/camili/)

\section{Ex situ Koruma}

$\mathrm{Bu}$ yöntemde ilgili türün doğal yaşam alanından alınarak başka bir ortama aktarılması ve koruma çalışmalarına bu yeni ortamda devam edilmesi sağlanmaktadır (Paunescu, 2009). Ex situ korumada türlerin evrimsel süreçlerinin kesintiye uğrama olasılığı dezavantaj olarak belirtilirken, in situ koruma yöntemlerindeki maliyetin yaklaşı \% 1 'i gibi bir maliyete sahip oluşu günümüzde bu yöntemlerin geliştirilmesindeki en önemli etmen olmuştur (Linington ve Pritchard, 2001). Ex situ koruma yaklaşımları arasında ilk ortaya çıkan yapılar botanik bahçeleri ve arboretumlardır. Bu yönüyle bakıldığında, dünya çapındaki yaklaşık 2204 botanik bahçesi ve arboretumunda (şekil 6) yeryüzündeki tohumlu bitki türlerinin yaklaşık 1/3'ünün yetiştirildiği ve korunduğu belirtilmektedir (BGCI Report, 2001).

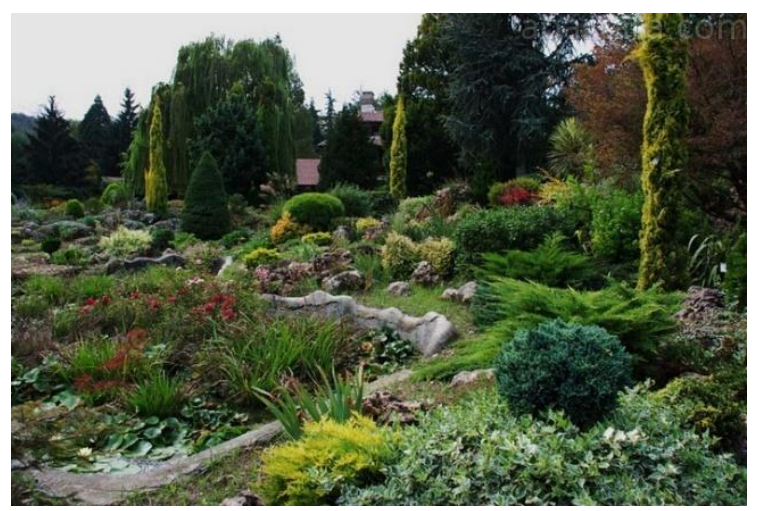

Şekil 6- Karaca Arboretumu/Yalova

(http://www.fazturkey.com/show/21/karaca-arboretum.aspx)

Tohum bankaları da bir başka -bitkileri ex situ koruma- yöntemidir (Linington ve Pritchard, 2001) (şekil 7,8). 


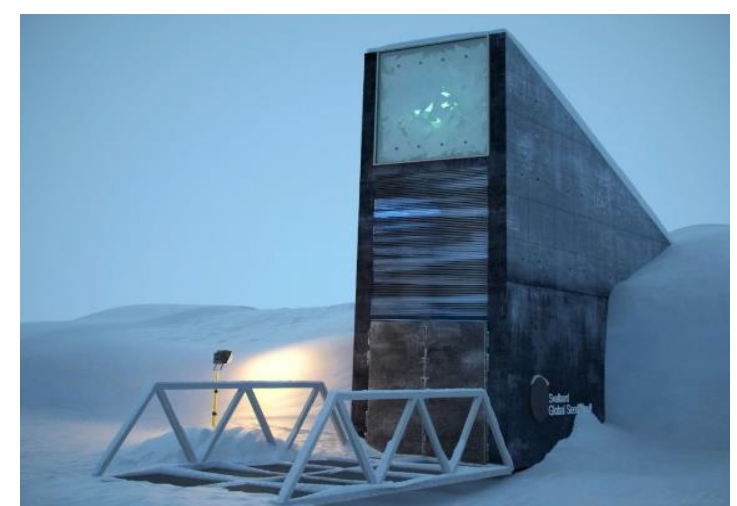

Şekil 7- Küresel Tohum Bankas1/Norveç (https://imgur.com/gallery/UvVggft)

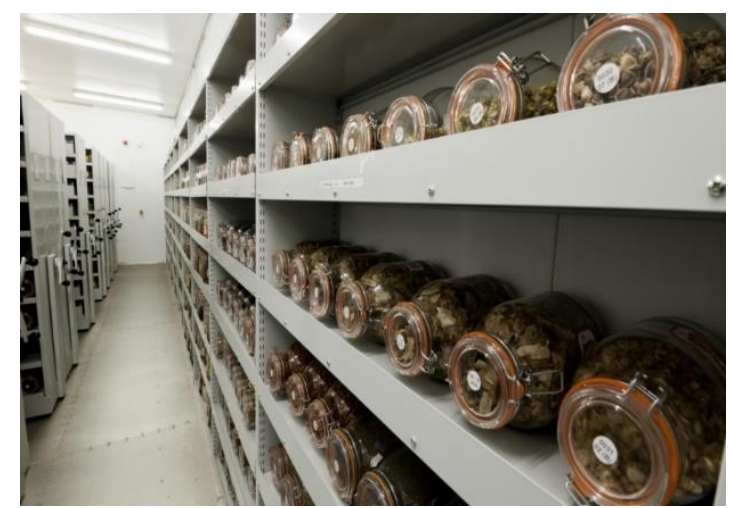

Şekil 8- Milenyum Tohum Bankas1/Kew Botanik Bahçeleri/İngiltere

(https://www.firstpost.com/tech/science/will-banking-on-seed-banks-take-focus-away-from-conservingnatural-habitats-5600241.html)

Tohum bankacılı̆̆ (tohum) nispeten küçük alanlarda depolanabilmesi gibi avantajlarıyla günümüzde hala rağbet görmektedir (https://www.bgci.org/resources/article/0134/).

Tarla ekimi genellikle ürün bitkilerinin korunması amacıyla kullanılan bir yöntemdir. Her sene aynı kültür çeşidine ait kayıtlı materyal ekilerek çeşidin her sene/dönem üretilmesi ve böylece sürekliliği sağlanır (Altieri vd., 2013).

Yukarıda sıraladığımız konvansiyonel ex situ yöntemlerine, 1980ler'den itibaren biyoteknolojik araçlar da katılmıştır (Yidana vd., 1987; Fay, 1992). Diğer bir deyişle, biyoteknolojideki in vitro kültüre alma (doku kültürü), kriyoprezervasyon ve moleküler işaretleme gibi gelişen teknikler bitki gen kaynaklarının ex situ korunmasında büyük bir alternatif ortaya çıkarmıştır (Cruz-Cruz vd., 2013). In vitro kültürlerle, bitkisel germplazm nispeten küçük alanlarda saklanmakta, bitki yetiştirme için mevsime bağlılık ortadan kalkmakta, doğal bitkilerin habitatlarından toplanarak yok edilme baskısı önemli ölçüde azalmakta ve ayrıca in vitro çoğaltılan bitkiler doğal ortamlarına geri aktarılarak populasyonlarının güçlendirilmesi sağlanabilmektedir (Chauhan, 2016; Oseni vd., 2018).

\subsection{Bitkisel materyalin in vitro kültürü}

In vitro kültüre alma terimi sürgün исu, meristem, somatik embriyo, embriyojenik kallus (şekil 9,10) vb. formdaki bitkisel germplazmın yapay besi ortamında ve steril şartlarda yetiştirilmesi anlamına gelir (Smith, 2013). 


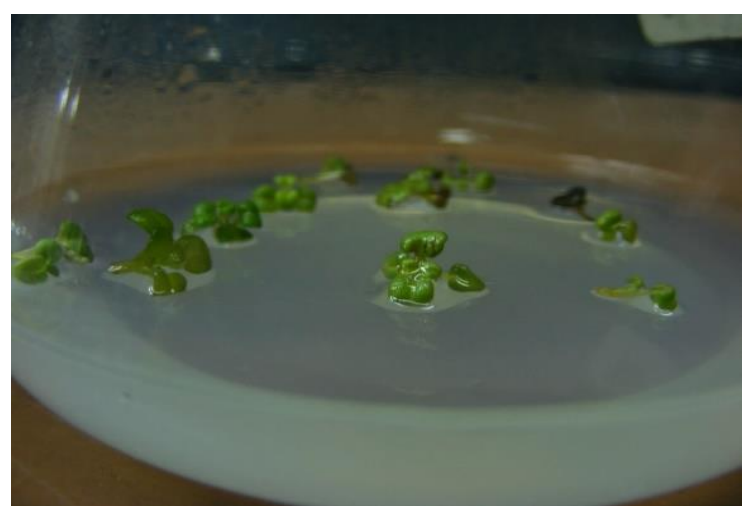

Şekil 9- Origanum sipyleum L. bitkisi sürgün ucu kültürü (Çakır, 2011).

Şekil 10- Papaver somniferum L. L. cv. Ofis-95 bitkisi embriyojenik kallus kültürü (Akçam Oluk ve Kaşkar, 2005).

Her tür için özgün protokoller gerekse de in vitro bir koleksiyon oluşturmadaki ortak aşamalar;

- kültür başlangıcı (şekil 11, Duran, 2010),

- başlatılan kültürün devamlılığı (şekil 12, Duran, 2010) ve

- çoğaltmadır (şekil 13, Duran, 2010).

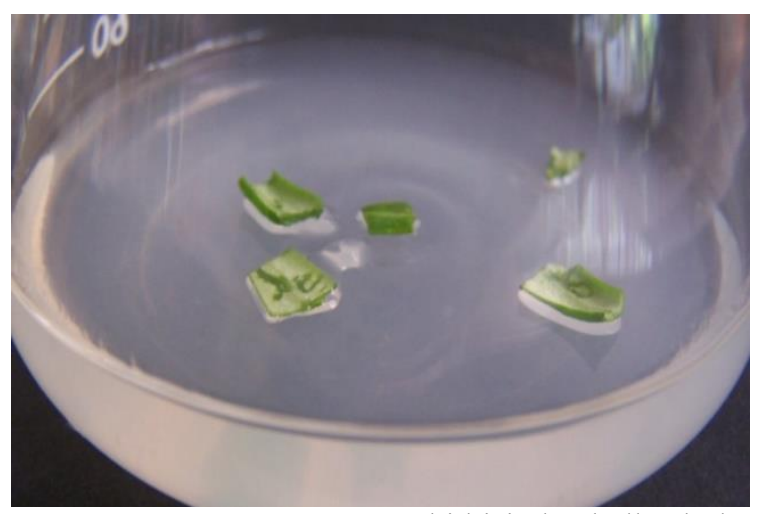

Şekil 11- Lycopersicon esculentum Mill. cv. SC2121 bitkisinden kallus kültürü başlatmak üzere besi ortamına yerleştirilmiş yaprak eksplantları (Duran, 2010) 


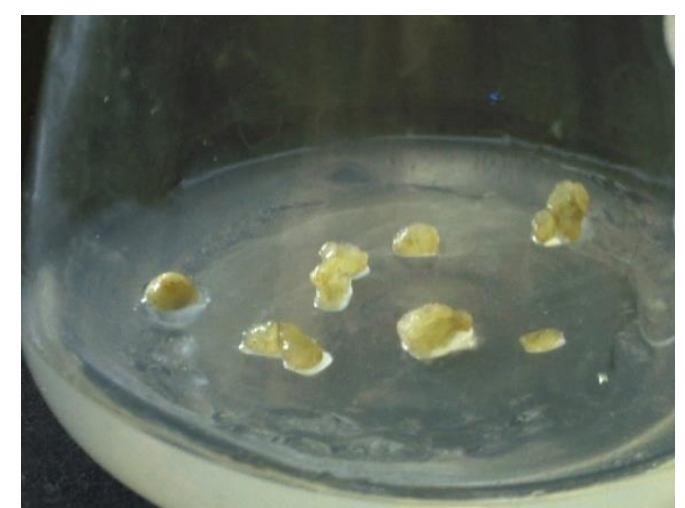

Şekil 12- Lycopersicon esculentum Mill. cv. SC2121 bitkisi yaprak eksplantları üzerinde 2 aylık kalluslar (Duran, 2010)

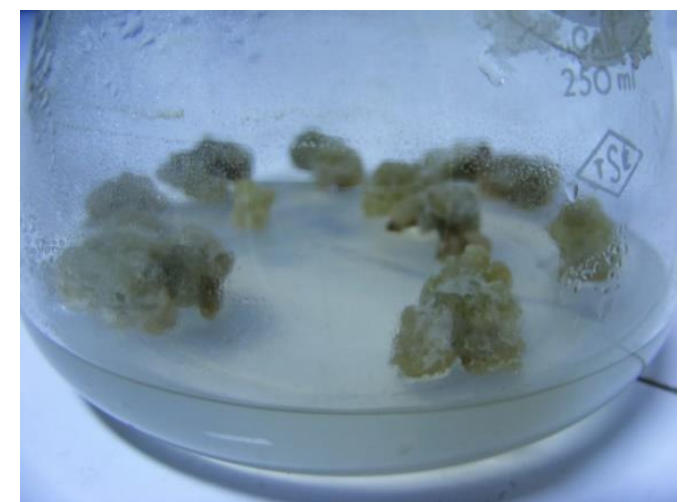

Şekil 13- Lycopersicon esculentum Mill. cv. SC2121 bitkisi yaprak eksplantlarından gelişen ve çoğaltılan 6 aylık kalluslar (Duran, 2010)

$\mathrm{Bu}$ tip kültüre alma genellikle laboratuvarlarda gerçekleştirilmekle birlikte doğrudan arazide yapılan çalışmalardan da söz edilmektedir (Pence, 2005). Arazide in vitro kültüre alma kısa süreli canlılığa sahip tohumlarda ve eksplant kaynağı bitkinin taşınmasının zor olduğu durumlarda kolaylık sağlamaktadır (Sarasan vd., 2006).

\subsection{In vitro kültürlerin saklanması (korunması)}

In vitro elde edilen ve çoğaltılan bitkisel materyal (kültür) klsa, orta ve uzun vadeli olarak üç şekilde saklanabilmektedir (Engelman vd., 2002).

Kısa vadeli saklama: İlk zamanlar in vitro kültürlerin basitçe "tekrarlı altkültürlerle" korunmasına çalışılmıştır. Ancak bu yöntem masraflı olduğu için (insan gücü, enerji, sürekli besi ortamı hazırlığ1, kontaminasyon riski vb.) daha sonra farklı yöntemlerin arayışına girilmiştir (Bhatia vd., 2015).

Orta vadeli saklama: Bu yöntemde fiziksel ve/veya kimyasal uygulamalarla bitkisel materyalin büyüme hızının düşürülmesi sağlanır (Bhatia vd., 2015). Fiziksel yöntemlerden sıcaklık uygulaması materyalin ait olduğu türe bağlı olarak değişir. Ilıman iklim bitkilerine ait in vitro koleksiyonlar $4{ }^{\circ} \mathrm{C}$ 'de saklanabilirken, tropikal bitkiler için $15-20{ }^{\circ} \mathrm{C}$ gerekmektedir (Tormann, 2006). Işıklandırma süresi (karanlık ya da 12-16 saatlik fotoperyod vb) ve 1şı yoğunluğu ise yine türe bağlı olacak şekilde ayarlanmaktadır (Villalobos ve Engelmann, 1995). Bu yöntemle orta-vadeli saklanabilmiş (korunabilmiş) in vitro kültürü yapılan tehlike altındaki (EN) türlere örnek olarak Artemisia tschernieviana, Astragalus pseudopurpureus, Cerastium transsilvanicum, Dianthus callizonus, D. spiculifolius, D.tenuifolius, Erigeron nanus, Hieracium pojoritense, ve Marsilea quadrifolia'y1 verebiliriz (Paunescu, 2009). Kimyasal yöntem olarak, in vitro kültüre alınan bitkisel materyalin yetiştirildiği mikroçevrenin (örn. besi ortamı) “oksijen seviyesinin düşürülmesi” uygulaması yapılmaktadır. Bu amaçla bitkisel materyal ince bir tabaka sıvı besi ortamıyla (besiyer) veya mineral yağıylal kaplanır (Martin vd., 1998). Ya da bitkiden alınan zigotik veya somatik embriyolar mikro ve

\footnotetext{
1 *:Mineral yağ, hafif alkenlerin karlşımıyla oluşan, bitkisel olmayan, petrol ürünü bir tür yă̆dır. Bu
} yă̆ sıvı parafin ya da sıvı petrol olarak da bilinir (http://www.mineral.gen.tr/mineral-yag.html). 
makro besleyiciler içeren özel bir matrikse (bkz. tablo 1) hapsedilir (enkapsulasyon). Böylece oluşan yapıya yapay tohum adı verilmektedir (Saiprasad, 2001; Rihan vd., 2017)(Şekil 14).

Tablo 1- Enkapsulasyonda kullanılan jeller ve kompleks yapıcı ajanlar (http://www.biologydiscussion.com/plant-tissues/artificial-seeds/artificial-seeds-meaning-method-formaking-and-importance/14674'dan düzenlnmiştir)

\begin{tabular}{llll}
\hline Jel & Derişim (\%) w/v & Kompleks Yapıcı Ajan & Derişim (\%) $\mathbf{m M}$ \\
\hline & & & \\
Na aljinat & $0.5-5.0$ & Ca tuzları & $30-100$ \\
Na aljinat & 2.0 & $\mathrm{CaCl}$ & $30-100$ \\
(jelatinle) & 5.0 & & \\
Karragenan & $0.2-0.8$ & $\mathrm{KCL}$ veya & 500 \\
(keçi boynuzu zamkıyla) & $0.4-1.0$ & $\mathrm{NH} 4 \mathrm{Cl}$ & \\
Jel rit & 0.25 & Sıcaklık düşürülmesi & \\
\hline
\end{tabular}

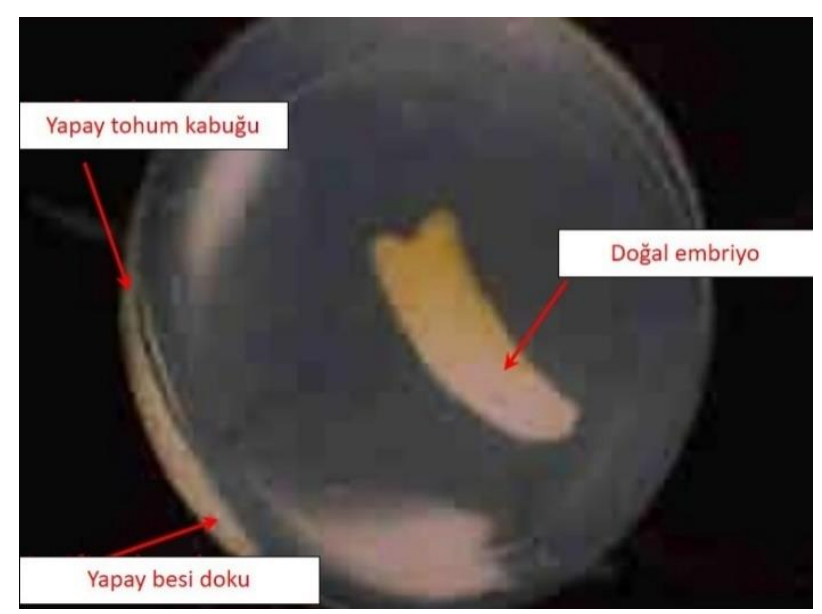

Şekil 14- Yapay tohum (https://www.slideshare.net/shivanandhort/synthetic-seedproduction'dan düzenlenmiştir)

Yapay tohum üretilen ve tehdit altında bulunan türler arasında Swertia chirayita (Roxb. Ex Fleming) H. Karst, Tylophora indica (Burm. Fil.) Merrill, Gentiana lutea L., Bacopa monnieri (L.) Wettst. sayllabilir (Saxena vd., 2019). Nesli tükenmekte olan bazı orkidelerin protokormlarının (vejetatif üreme materyali) da bu yolla $4{ }^{\circ} \mathrm{C}$ 'de 6 ay boyunca saklanabildikleri rapor edilmiştir (Devi vd., 1998).

Uzun vadeli saklama: $\mathrm{Bu}$ amaçla kullanılan yöntem kriyoprezervasyondur (cryo=soğuk, prezervasyon=koruma; kriyoprezervasyon= soğukta koruma). Bu yöntemde önce,

- bitkisel materyaldeki (polen, kallus, embriyo, organ parçaları vb.) tüm donabilir sıvı, fiziksel veya ozmotik dehidrasyon ile ortadan kaldırılır;

- ve hemen ardından işlem görmüş bu bitki materyali, hücre içindeki tüm çözünebilen maddeler (solut) vitrifiye (kristalleşmeden donma) olacak şekilde, çok düşük sıcaklıklarda (genellikle azotun $-196^{\circ} \mathrm{C}^{\prime}$ lik sıvı veya $-150^{\circ} \mathrm{C}^{\prime}$ lik buhar fazında) $)^{2}$ saklanır (Şekil 15).

\footnotetext{
${ }^{2}$ Azot katl faz $=-210^{\circ} \mathrm{C}$, slvl faz $=-196^{\circ} \mathrm{C}$, buhar fazl $-190^{\circ} \mathrm{C}$ ve üstü (https://sploid.gizmodo.com theres-liquid-nitrogen-turning-into-solid-nitrogen-in-an-1596220284)
} 


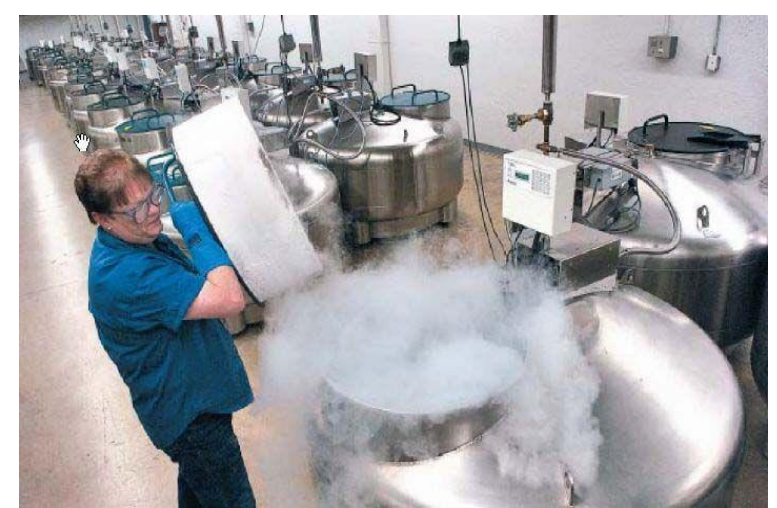

Şekil 15- Kriyoprezerrvasyon tanklar1 (https://www.ars.usda.gov/plains-area/fort-collins-co/center-foragricultural-resources-research/plant-and-animal-genetic-resources-preservation/docs/welcome-andtour/)

$\mathrm{Bu}$ düşük sıcaklıklar canlı yapıdaki bütün metabolik etkenlikleri, $i$ ) genetik değişiklik riskini en alt seviyeye indirerek ve $i$ ) besi ortamı yenileme ihtiyacını ortadan kaldırarak baskılayabilmektedir (Şekil 16).

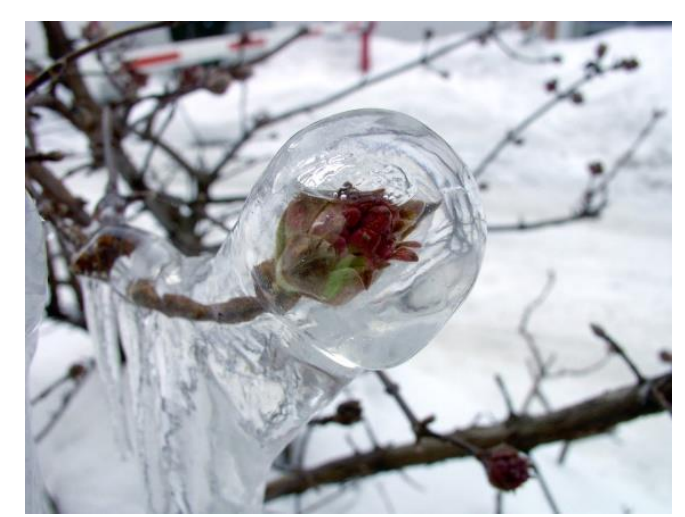

Şekil 16- Doğal kriyoprezervasyon (!) https://logeg.deviantart.com/art/Natural-cryopreservation122794747

Kriyoprezervasyon tekniğinde bundan sonraki aşama, ihtiyaç duyulan zaman diliminde bitkisel materyalin çözülerek yaşamına kaldığı yerden devamının sağlanmasıdır (Tormann vd., 2006)(Şekil 17).

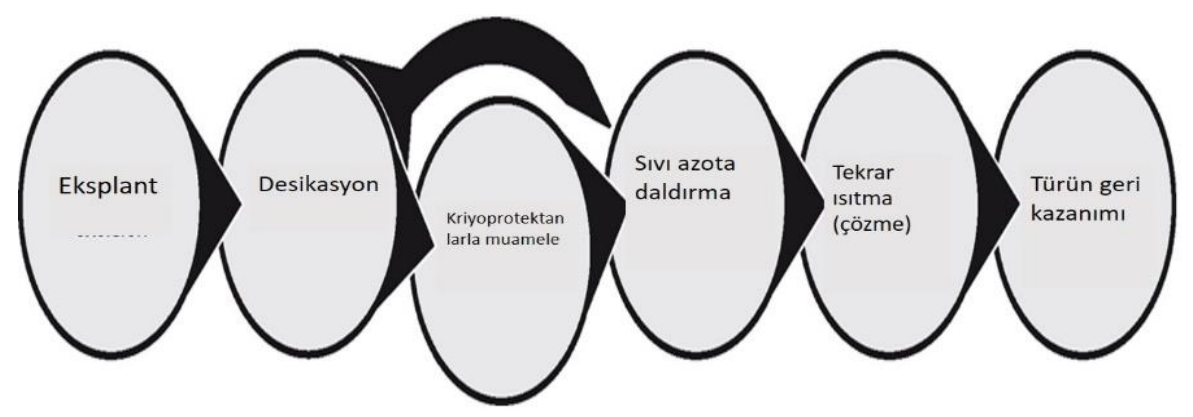

Şekil 17-Türlerin korunmasında kriyoprezervasyon tekniği aşamaları (Streczynski vd., 2019'dan düzenlenmiştir)

Farmasötik öneme sahip bazı bitki hücre süspansiyon (Frinkle vd., 1985) ve kallus (Spencer, 1999) kültürleri ile endemik bazı bitki sürgün ucu kültürlerinin (Malon vd., 2008) başarılı bir şekilde kriyoprezervasyonunun yapıldığ 1 rapor edilmiştir. Hindistan Bahçe Bitkileri Araştırma Enstitüsü (Indian Institute for Agricultural Research (IIHR)/Bangalore) 'nde ise 15 familyadan 40 türe ait 600 polen 
örneğinin, bazıları 15 yıldır olmak üzere, kriyoprezervasyon ile saklandığı (korunduğu) belirtilmektedir (Ganeshan ve Rhajashekaran, 2000).

\subsection{Saklanan bitkisel materyalde genetik kararlılık}

Üstte söz ettiğimiz yöntemlerle saklanan (korumaya alınan) bitkisel örneğin, türe bağlı olarak, kontrol materyalle karşılaştırılarak ve gözlem yoluyla, $i$ ) her 1-3 ayda bir kontrol edilmesi gerekir (Paunescu, 2009). Gözlemler sırasında herhangi bir anormallik görülürse ii) saklanan örnek çıkarılarak sera şartlarında yetiştirilir ve morfolojik bir farklılık olup olmadığ 1 kontrol edilir. Üçüncü aşamada, morfolojik farklılık olsun olmasın, ii) materyal biyokimyasal ve/veya moleküler biyolojik testlere tabi tutulur. Biyokimyasal testlerde biyokimyasal işaretleyiciler kullanılır. Özelde, protein işaretleyiciler (tohum depo proteinleri ve izozimler) olarak da bilinen bu maddeler elektroforez ile elde edilmekte ve özel doku-kimyasal boyalarla boyanarak görünür hale gelmektedir. Bitki genetik stabilizasyonunun belirlenmesinde bugüne kadar (2009 yıll, bkz. Paunescu, 2009) yaklaşık 90 izozim sisteminin kullanıldığı rapor edilmiştir. Örn., EN kategorisindeki İspanya endemiği Centaurium rigualii bitkisinin genetik stabilitesi yedi izozim sistemi kullanılarak başarılı bir şekilde çalışılmıştır (Iriondo ve Perez, 1996).

Moleküler testlerde ise moleküler (DNA) işaretleyiciler kullanılmaktadır. Bu maddeler başlangıç DNA'sından türetilir ve oluşturulan teknolojiyle DNA polimorfizmi hem çekirdek hem de organel DNA'sında belirlenebilir. Günümüzde ,genetik çeşitliliğin ya da stabilitenin en iyi şekilde ölçülmesini sağladığı belirtilen bu teknikler arasında,

- PCR (Polymerase Chain Reaction),

- RFLP (Restriction Fragment Length Polymorphism),

- AFLP (Amplified fragment length polymorphism),

- RAPD (Random amplified polymorphic DNA),

- SCAR (Sequence characterized amplified region),

- SSR (Simple sequence repeat),

- ISSR (Inter simple sequence repeat),

- ve Mikrosatellitler sayllabilir (Govindaraj vd., 2015).

Moleküler işaretleyicilere tamamlayıcı yöntem olarak kullanılan "akım sitometrisi” ile de DNA içeriği veya ploidi seviyelerinde meydana gelebilecek olası değişiklikler belirlenmektedir (Fukai, 2002).

\section{Değerlendirme}

İrdelediğimiz çalışmalardan anlaşıldığına göre, endemik, nadir bulunan ve tehdit altındaki bitki türleri uzun yıllar "doğal rezerv alanları, milli parklar vb." bölgelerde in situ korunmaya alınmıştır. Bu koruma yönteminin zahmetli ve özellikle pahalıya mal oluşu, bu konuda çalışanları yeni yöntemler bulmaya teşvik etmiş ve sonuç olarak türlerin doğal yayılış alanlarından başka alanlarda (botanik bahçeleri, arboretum vb) yetiştirilmesi gibi alternatif bir yaklaşımı ortaya çıkarmıştır (konvansiyonel ex situ koruma). 1980lerden itibaren ise ex situ koruma çabalarının içine, modern tabir edebileceğimiz, biyoteknolojik yöntemler dahil olmaya başlamıştır. Bu kapsamda, özellikle bitki doku kültürü yöntemleriyle, tehdit altında olan bireyin koruma materyalinin (tüm bitkiden $\rightarrow$ hücre, embriyo, tohum, tepe tomurcuğuna $\mathrm{vb}$ ) ve koruma çalışması alanının (tarladan $\rightarrow$ laboratuvar koşullarına) minimalize edilmesi tekniğin öne çıkan yönleri olmuştur. Yine bu teknik sayesinde, bitkisel germplazmın alt kültürlerle kısa; soğuk ya da oksijensiz ortamda orta; ve dondurarak uzun vadede korunabilmesinin sağlandığı görülmektedir. İlaveten, moleküler biyolojik ve biyokimyasal testlerle uzun süreli korunan bitkisel materyalde genetik değişikliklerin olup olmadığı belirlenebilmektedir. Sonuç olarak, biyoteknolojik yöntemlerin yok olma tehlikesiyle karşs karşıya olan bitki türlerinin koruma ve sslah programlarında rutin olarak kullanılır hale geldiği ve botanik bahçeleri ve diğer araştırma merkezleri arasında bilgi ve materyal alışverişine büyük kolaylık getirdiği söylenebilir.

\section{Kaynakça}

Akçam Oluk E, Kaşkar Ç. 2005. Somatic embryogenesis and shoot regeneration from callus cultures of Papaver somniferum L. cv. office -95, Akdeniz Üniversitesi Ziraat Fakültesi Dergisi, 18(2), $225-227$

Alho CJR. 2012. The importance of biodiversity to human health: an ecological Perspective, Estudos Avançados, 26(74), 151-166 
Altieri MA, Anderson MK, Merrick LC. 1987. Peasant Agriculture and the Conservation of Crop and Wild Plant Resources, Conservation Biology, 1(1),49-58

Bhatia S, Sharma K, Dahiya R, Bera T. 2015. Modern Applications of Plant Biotechnology in Pharmaceutical Sciences, Academic Press, Elsevier, p.452

BGCI Reports. 2001.Summary of the international review of the ex situ plant collections of the botanic gardens of the world. BGCI News, 3(7)

Chapin FS.3rd. 2003. Effects of plant traits on ecosystem and regional processes: a conceptual framework for predicting the consequences of global change. Annals of Botany, 91(4), 455-463, doi:10.1093/aob/mcg041

Cruz-Cruz C. et al. 2013. Biotechnology and Conservation of Plant Biodiversity, Resources, 2, 73 95

Çakır A. 2011. Batı Anadolu endemiği Origanum sipyleum L. (Kekik) bitkisinin in vitro mikroçoğaltımı ve mikrobitkilerde uçucu yağ içeriğinin araştırılması, YL Tezi, E.Ü. Fen Bil. Enst., $54 \mathrm{~s}$.

Dev1 J, Ray BK, Chet1a S, Deka, PC. 1998. Regeneration of low temperature stored encapsulated protocorms of orchids, J.Orchid Soc.India, 12, 39-41

De-Zhu L, Pritchard HW. 2009. The science and economics of ex situ plant conservation, Trends in Plant Science, 14(11), 614-621

Duran H. 2010. Domates (Lycopersicon esculentum Mill.) bitkisinden in vitro borca zengin ortamda kallus eldesi, YL Tezi, E.Ü. Fen Bil. Enst., $40 \mathrm{~s}$.

Engelmann F, Engels JMM. 2002. Technologies and strategies for ex situ conservation. In: Managing Plant Genetic Diversity, CABI, 89-103

Fay MF. 1992. Conservation of rare and endangered plants using "in vitro" methods. In Vitro Cell. Dev. Biol., 28,1-4

Frankel OH, Soule ME. 1981. Conservation and Evolution, Cambridge Univ Pres., England, p.311

Frinkle BJ, Zavala ME, Ulrich JM. 1985. Cryoprotective compounds in the viable freezing of plant tissues, In: Cryopreservation of plant cells and organs, Kartha KK. ed., CRC Press, Boca Raton ,Florida, pp.75-113

Fukai S, Hasegawa A, Goi M. 2002. Polysomaty in Cymbidium, HortScience, 37,1088-1091

Ganeshan S, Rajashekaran PE. 2000. Current status of pollen cryopreservation research: relevance to tropical agriculture. In: Engelmann F, Takagi H. eds., Cryopreservation of tropical plant germplasm - current research progress and applications, Tsukuba: JIRCAS; 360-365 (Rome: IPGRI).

Govindaraj M, Vetriventhan M, Srinivasan M. 2015. Importance of Genetic Diversity Assessment in Crop Plants and Its Recent Advances: An Overview of Its Analytical Perspectives, Hindawi Publishing Corporation Genetics Research International Volume 2015, Article ID 431487, 14 pages http://dx.doi.org/10.1155/2015/431487

Holobiuc I, Blındu R. 2007. In vitro culture introduction for ex situ conservation of some rare plant species, Rom. J. B1ol, 52,13-23 
Hunter P. 2007. The human impact on biological diversity. How species adapt to urban challenges sheds light on evolution and provides clues about conservation, EMBO reports, 8(4), 316-318. doi:10.1038/sj.embor.7400951

Iriondo JM, Perez C. 1996. Micropropagation and in vitro storage of Centaurium rigualii Esteve (Gentianaceae), Isr. J. Plant Sci., 44, 115-123

IUCN Red List of Treatened Species Version 3.1 (IUCN, accessed June 2016)

Linington SH Pritchard HW. 2001. Genebanks. In: Encyclopaedia of Biodiversity, Volume 3, (S.A. Levin, ed.), pp. 165- 181, Academic Press, San Francisco

Mallón R, Bunn, E, Turner, S, Gonzalez, M. 2008. Cryopreservation of Centaurea ultreiae (Compositae) A Critically Endangered Species from Galicia (Spain), Cryo letters, 29, 363-370

Martin C. et al. 1998. The use of tissue culture techniques in the conservation of plant biodiversity, Agri-Food-Industry Hi-Tech, 1(9), 37-40

Nag KK, Street HE. 1973. Carrot embryogenesis from frozen cultured cells, Nature, 245, 270-272

Oseni OM. 2018. A Review on Plant Tissue Culture, A Technique for Propagation and Conservation of Endangered Plant Species, International Journal of Current Microbiology and Applied Sciences, 7. 10.20546/ijcmas.2018.707.438.

Pence V.C. 2005. In vitro collecting (IVC). 1.The effect of collecting method and antimicrobial agents on contamination in temperate and tropical collections, In Vitro Cell. Dev. Biol. Plant, 41,324332

Quatrano RS. 1968. Freeze preservation of cultured flax cells utilizing dimethyl sulfoxide, Plant Physiol, 43, 2057-2061

Ramsay MM, Jacskon AD, Porley RD. 2000. A pilot study for ex situ conservation of UK bryophytes. In: BGCI, ed. EuroGard 2000 - EBGC, Canary Islands, Spain, Las Palmas de Gran Canaria: 5257

Samuel MC. 1959. Mineral oil overlay for conservation of plant tissue cultures Am. J. Bot, 46(5),324329

Sarasan V. et al. 2006. Conservation in-vitro of threatened plants progress in the past decade, In Vitro Cell. Dev. Biol—Plant, 42,206-214

Saxena A, Shukla M, Saxena P. (2019). Synthetic Seeds: Relevance to Endangered Germplasm Conservation In Vitro. 10.1007/978-3-030-24631-0_2.

Smith RH. 2013. Plant Tissue Culture:Techniques and Experiments, 3rd Edition, p.208, Academic Press, Elsevier

Solti PS. 2007. Plants, biodiversity, and climate change, BioScience, 57(9),783-786

Spencer M. 1999. The challenges of developing cryopreservation strategies to suit the requirements of a large industrial in vitro plant cell collection. In: Abstracts Cryo'99, World Congress of Cryobiology, Marseilles, 245 (France, July 12-15)

Stanwood PC, Bass LN. 1982. Seed germplasm preservation using liquid nitrogen, Seed Sci. Technol., 9(2), 423-437

Streczynski R. et al. 2019. Current issues in plant cryopreservation and importance for ex situ conservation of threatened Australian native species, Australian Journal of Botany, 67, 1-15. 
Thormann I, Dulloo M, Engels J. 2006. Techniques for ex situ plant conservation.. 10.1300/5546_02.

Villalobos VM, Engelmann F. 1995. Ex situ conservation of plant germplasm using biotechnology, World ]ournal of Microbiology \& Biotechnology, 1, 375-382

Yidana JA, Withers LA, Ivins J. 1987. Development of a simple method for collecting and propagating cocoa germplasm in vitro, Acta Hortic, 212, 95-98

https://www.ars.usda.gov/plains-area/fort-collins-co/center-for-agricultural-resourcesresearch/plant-and-animal-genetic-resources-preservation/docs/welcome-and-tour/

http://www.biologydiscussion.com/plant-tissues/artificial-seeds/artificial-seeds-meaning-methodfor-making-and-importance/14674

https://logeg.deviantart.com/art/Natural-cryopreservation-122794747

http://www.mineral.gen.tr/mineral-yag.html

https://www.slideshare.net/shivanandhort/synthetic-seed-production

https://sploid.gizmodo.com/heres-liquid-nitrogen-turning-into-solid-nitrogen-in-an-1596220284

https://www.iucnredlist.org/

IPBES Raporu.2019. https://ipbes.net/news/Media-Release-Global-Assessment 